\title{
Pengaruh Konsentrasi GA3 Dan Dosis Pupuk N Terhadap Pertumbuhan Dan Hasil Tanaman Selada (Lactuca sativa L.)
}

\author{
Ranti Wijaya \\ Fakultas Pertanian Universitas Muhammadiyah Sorong
}

\begin{abstract}
This research aims to study the effect of the interaction of the solution concentration gibberellin $\left(\mathrm{GA}_{3}\right)$ and $\mathrm{N}$ fertilizer on the growth and yield of lettuce. Implementation of the experiments conducted in the village of Babakan Peuteu, District Cicalengka, Bandung. The experiment was based on a randomized blok design factorial pattern, which consist of two levels of each factor treatment consist of four levels, namely the concentration of $\mathrm{GA}_{3}$ and fertilizer $\mathrm{N}$ were replicated twice. Observations were made on the germination, growth rate, number of leaves, increasing the number of leaves, plant height, leaf area, fresh weight, shoot root ratio, and total dry weight of lettuce plants. The results show the effect of the inetraction occured between $\mathrm{GA}_{3}$ concentration and dose of fertilizer $\mathrm{N}$ to the age of 37 day leaf area, fresh weight per plant and dry weight per plant. Not occur interaction effect between $\mathrm{GA}_{3}$ concentration and dose of fertilizer $\mathrm{N}$ to the number of leaves, increasing the number of leaves, plant height at 22 days after planting, 27 days, 32 days, and 37 days after planting, leaf area at age 22 days, 27 days, and 32 days after planting and shoot root ratio. Giving $\mathrm{GA}_{3}$ concentration of $40 \mathrm{mgL}^{-1}$ $60 \mathrm{mgL}^{-1}$ and $\mathrm{N}$ fertilizer dose of $0.48 \mathrm{~g}$ poly $^{-1}$ to $0.72 \mathrm{~g}$ of poly ${ }^{-1}$ provides a broad leaves age 37 days and fresh weight/better results, while giving $\mathrm{GA}_{3}$ concentration of 60 $\mathrm{mgL}^{-1}$ and $\mathrm{N}$ fertilizer dose of $0.72 \mathrm{~g}$ poly ${ }^{-1}$ provides a dry weight age 37 day the best.
\end{abstract}

Key words : $\mathrm{GA}_{3}$, fertilizer $\mathrm{N}$, lettuce

\begin{abstract}
Abstrak
Penelitian ini bertujuan untuk mempelajari pengaruh interaksi konsentrasi larutan giberelin $\left(\mathrm{GA}_{3}\right)$ dan dosis pupuk $\mathrm{N}$ terhadap pertumbuhan dan hasil tanaman selada. Pelaksanaan percobaan dilakukan di desa Babakan Peuteu, Kecamatan Cicalengka, Kabupaten Bandung. Percobaan disusun dengan Rancangan Acak Kelompok pola faktorial, terdiri dari dua taraf faktor perlakuan masing-masing faktor terdiri dari empat taraf, yaitu konsentrasi $\mathrm{GA}_{3}$ dan dosis pupuk $\mathrm{N}$ yang diulang dua (2) kali. Pengamatan dilakukan terhadap daya kecambah, kecepatan tumbuh, jumlah daun, penambahan jumlah daun, tinggi tanaman, luas daun, bobot segar, nisbah pupus akar, dan bobot kering total tanaman selada. Hasilnya menunjukkan terjadi pengaruh interaksi antara konsentrasi $\mathrm{GA}_{3}$ dan dosis pupuk $\mathrm{N}$ terhadap luas daun umur $37 \mathrm{hst}$, bobot segar per tanaman dan bobot kering per tanaman. Tidak ada pengaruh interaksi antara konsentrasi $\mathrm{GA}_{3}$ dan dosis pupuk $\mathrm{N}$ terhadap jumlah daun, penambahan jumlah daun, tinggi tanaman pada umur 22 hst, 27 hst, 32 hst, dan 37 hst, luas daun pada umur 22 hst, 27 hst, dan 32 hst serta nisbah pupus akar. Pemberian konsentrasi $\mathrm{GA}_{3} 40 \mathrm{mgL}^{-1}-60$ $\mathrm{mgL}^{-1}$ dan dosis pupuk $\mathrm{N} 0,48 \mathrm{~g}$ polybag ${ }^{-1}-0,72 \mathrm{~g}$ polybag $^{-1}$ memberikan luas daun umur 37 hst dan bobot segar/hasil yang lebih baik, pemberian konsentrasi $\mathrm{GA}_{3} 60 \mathrm{mgL}^{-1}$ dan dosis pupuk $\mathrm{N}$ 0,72 $\mathrm{g} \mathrm{polybag}^{-1}$ memberikan bobot kering umur 37 hst yang terbaik.
\end{abstract}

Kata kunci : $\mathrm{GA}_{3}$, pupuk N, tanaman selada 


\section{PENDAHULUAN}

Selada (Lactuca sativa L.) Merupakan salah satu tanaman yang banyak memiliki nilai positif. Selada mempunyai kandungan mineral, termasuk iodium, fosfor, besi, tembaga, kobalt, seng, kalsium, mangan, dan potasium, sehingga selada mempunyai khasiat terbaik dalam menjaga keseimbangan tubuh.

Selain kandungan gizi yang dimiliki, selada (Lactuca sativa L.) juga merupakan salah satu komoditas hortikultura yang memiliki nilai ekonomis tinggi. Kebutuhan manusia yang terus berkembang disertai kesadaran akan nilai gizi yang diperlukan telah mendorong pada peningkatan jumlah konsumsi sayuran. Ditinjau dari aspek teknis, ekonomis dan bisnis, selada layak diusahakan untuk memenuhi permintaan konsumen yang cukup tinggi dan peluang pasar internasional yang cukup besar (Haryanto dkk, 1995).

Selada dikembangbiakkan melalui biji, namun persentase perkecambahan benih selada berkisar 40\%-77\%. Hak ini menyebabkan petani kurang berminat untuk membudidayakan selada. Di lapangan ditemukan perkecambahan selada kurang dari 50\% (Surtinah, 2010).

Melihat rendahnya persentase perkecambahan dan semakin meningkatnya permintaan selada yang menandakan pula prospek yang cukup bagus di masa yang akan datang maka perlu adanya peningkatan produksi dari tanaman selada. Diupayakan pula mempercepat usia panennya untuk memenuhi konsumsi di masyarakat khususnya di wilayah Indonesia Timur yang masih jarang dengan harga yang cukup tinggi.
Meningkatkan hasil dengan mempercepat usia panen bisa dilakukan dengan menambahkan zat pengatur tumbuh dengan dosis tertentu. Dengan ini diharapkan mampu mempercepat perkecambahan dan pertumbuhan selada khususnya pada organ daun dan umur panen bisa dilakukan lebih cepat. Zat pengatur tumbuh (ZPT) yang sering digunakan adalah jenis giberelin dikarenakan dapat mempercepat perkecambahan dan diharapkan mampu mempercepat pertumbuhan vegetatif tanaman selada.

Ogawa dkk (2003) menyatakan bahwa giberelin memainkan peran penting dalam perkecambahan arabidopsis. Giberelin juga dapat berpengaruh dalam menginduksi bunga pada tanaman tropis (Henny and Chen, 2011). Pemberian hormon tanaman unggul (pupuk yang mengandung giberelin) pada benih selada mampu meningkatkan kecepatan perkecambahan, tinggi benih dan waktu pindah tanam pada benih selada (Surtinah, 2010)serta pembungaan, kuantitas dan kualitas pada benih cabai merah keriting (Arifin dkk, 2012).

Upaya untuk mempercepat pertumbuhan vegetatif tanaman selada juga dapat dilakukan deangan penambahan dosis pupuk N. Pupuk N diperlukan untuk pembentukan atau pertumbuhan bagianvegetatif tanaman, seperti daun, batang dan akar. Pupuk N juga berperan penting dalam pembentukan hijau daun yang berguna dalam fotosintesis, membentuk protein, lemak dan berbagai persenyawaan organik, meningkatkan mutu tanaman penghasil dedaunan, serta meningkatkan perkembangbiakan mikroorganisme di dalam tanah.

Nugroho (2005) menyebutkan perbedaan dosis Urea berpengaruh 
sangat nyata terhadap pertumbuhan tinggi tanaman, jumlah daun, dan berat brangkasan segar serta terdapat hasil berat konsumsi/tanaman dan berat konsumsi/petak. Sedangkan hasil tertinggi untuk tanaman selada adalah pemupukan dengan dosis 1,8 g/tanaman.

Perendaman benih selada pada konsentrasi $\mathrm{GA}_{3}$ dan penambhan dosis pupuk $\mathrm{N}$ diharapkan mampu secara sinergis memberikan pengaruh terhadap pertumbuhan dan hasil tanaman selada. Untuk itu perlu dilakukan sebuah penelitian yang akan memberikan informasi mengenai pengaruh konsentrasi giberelin $\left(\mathrm{GA}_{3}\right)$ sebagai zat pengatur tumbuh dan dosis $\mathrm{N}$ yang terbaik untuk pertumbuhan dan hasil tanaman selada.

\section{METODE PENELITIAN}

Penelitian dilakukan di Desa Babakan Cipeutey, Kecamatan Cicalengka, Kabupaten Bandung. Untuk menjaga keseragaman lingkungan mikro, percobaan dilakukan dalam bangunan rumah beratap plastik serta sisi bangunan menggunakan paranet untuk meminimalisir hama, penyakit dan hembusan angin kencang. Penelitian dilakukan dari bulan Agustus sampai bulan September 2014.

Bahan yang digunakan diantaranya benih selada kultivar Belini, giberelin $\left(\mathrm{GA}_{3}\right)$ Mad Gib GA-3 20\%, pupuk urea, polybag, tanah dan air. Sedangkan alat yang digunakan adalah pisau, meteran, gelas plastik, baskom, stopwatch, termohigrometer, timbangan analitik, gelas ukur, pipet tetes, corong, sekop, sendok, mistar ukur, ember plastik, kamera dan alat tulis.

Pendekatan eksperimen yang digunakan adalah RAK (Rancangan Acak Kelompok) pola faktorial, yang terdiri dari dua faktor perlakuan masing-masing faktor terdiri dari empat taraf, yaitu konsentrasi $\mathrm{GA}_{3}$ dan dosis pupuk $\mathrm{N}$ yang diulang dua (2) kali.

Tabel 1. Kombinasi Konsentrasi GA $\mathrm{G}_{3}$ dan Dosis Pupuk N

\begin{tabular}{ccccc}
\hline Konsentrasi ZPT & \multicolumn{4}{c}{ Dosis pupuk N (d)(gram) } \\
\cline { 2 - 5 } $\mathrm{GA}_{3}(\mathrm{c})(\mathrm{mgL}-1$ air $)$ & $\mathrm{d} 1$ & $\mathrm{~d} 2$ & $\mathrm{~d} 3$ & $\mathrm{~d} 4$ \\
\hline $\mathrm{c} 1$ & $\mathrm{c} 1 \mathrm{~d} 1$ & $\mathrm{c} 1 \mathrm{~d} 2$ & $\mathrm{c} 1 \mathrm{~d} 3$ & $\mathrm{c} 1 \mathrm{~d} 4$ \\
$\mathrm{c} 2$ & $\mathrm{c} 2 \mathrm{~d} 1$ & $\mathrm{c} 2 \mathrm{~d} 2$ & $\mathrm{c} 2 \mathrm{~d} 3$ & $\mathrm{c} 2 \mathrm{~d} 4$ \\
$\mathrm{c} 3$ & $\mathrm{c} 3 \mathrm{~d} 1$ & $\mathrm{c} 3 \mathrm{~d} 2$ & $\mathrm{c} 3 \mathrm{~d} 3$ & $\mathrm{c} 3 \mathrm{~d} 4$ \\
$\mathrm{c} 4$ & $\mathrm{c} 4 \mathrm{~d} 1$ & $\mathrm{c} 4 \mathrm{~d} 2$ & $\mathrm{c} 4 \mathrm{~d} 3$ & $\mathrm{c} 4 \mathrm{~d} 4$ \\
\hline
\end{tabular}

Adapun tahapan percobaan diawali dengan penyiapan benih. Benih yang digunakan adalah varietas Belini yang telah tersertifikasi.

Persiapan larutan $\mathrm{ZPT} \mathrm{GA}_{3}$. $\mathrm{GA}_{3}$ dilarutkan dalam air sesuai dengan konsentrasi yang ditetapkan dalam percobaan. $\mathrm{GA}_{3}$ yang digunakan adalah Mad Gib ( $\left.\mathrm{GA}_{3} 20 \%\right)$. Konsentrasi 20 $\mathrm{mgL}^{-1}$ berarti melarutkan $20 \mathrm{mg} \mathrm{GA}_{3}$ dalam satu liter air. Konsentrasi $\mathrm{GA}_{3} 40$ $\mathrm{mgL}^{-1}$ berarti melarutkan $40 \mathrm{mg} \mathrm{GA} 3$ dalam 1 liter air. Konsentrasi $\mathrm{GA}_{3} 60$
$\mathrm{mgL}^{-1}$ berarti melarutkan $60 \mathrm{mg} \mathrm{GA}_{3}$ dalam 1 liter air.

Perendaman. Benih selada direndam dalam konsentrasi larutan $\mathrm{GA}_{3} 20 \mathrm{mgL}^{-1}$ larutan, $40 \mathrm{mgL}^{-1}$ larutan dan $60 \mathrm{mgL}^{-1}$ larutan selama 15 menit.

Perkecambahan . benih disebar secara merata pada kotak perkecambahan dengan mediaberupa campuran tanah, pupuk kandang kambing dan pasir dengan perbandingan $2: 1: 1$, kemudian ditutupi dengan lapisan tanah tipis-tipis. Perkecambahan 
dilakukan di ruangan semacam rumah kaca.

Persiapan media tanam. Persiapan media tanam untuk percobaan dilakukan dengan mengambil contoh tanah Inceptisol secara komposit dari beberapa tempat pada lapisan olah sedalam $30 \mathrm{~cm}$ dari lapangan. Setelah itu tanah tersebut dikeringanginkan selama 2 hari, selanjutnya dihaluskan dan disaring dengan saringan yang berdiameter $2 \mathrm{~mm}$. Tanah tersebut dicampur dengan pupuk kandang kambing dengan perbandingan $2: 1$, dan dimasukkan dalam polybag. Setiap perlakuan terdapat 10 polybag, maka seluruhnya terdapat 320 polybag. Tiap perlakuan disusun dengan jarak tanam $20 \times 25 \mathrm{~cm}$ dan diberi label sesuai dengan kode perlakuan dan tata letak percobaan.

Penanaman.

Penanaman

dilakukan secara langsung. Penanaman dilakukan dengan menanam 3 benih selada. Jika terdapat tanaman yang mati atau tumbuh tidak normal dilakukan penyulaman.

Pemupukan.

Pemupukan dilakukan saat tanaman selada memiliki empat (4) daun yaitu pada umur $17 \mathrm{hst}$. Penambahan pupuk $\mathrm{N}$ dengan dosis $0,24 \mathrm{~g}$ polybag $^{-1}\left(0,6 \mathrm{~g}\right.$ polybag $^{-1}$ Urea $)$; $0,48 \mathrm{~g}$ polybag $^{-1}\left(1,2 \mathrm{~g}\right.$ polybag $^{-1}$ Urea) dan $0,72 \mathrm{~g} \mathrm{polybag}^{-1}\left(1,2 \mathrm{~g}\right.$ polybag $^{-1}$ Urea) pada setiap perlakuan konsentrasi $\mathrm{GA}_{3}$.

Pemeliharaan. Penyiraman dilakukan pagi dan sore. Penyulaman dilakukan pada saat tanaman terlihat tumbuh abnormal, biasanya sudah terlihat saat tanaman berumur 5 hst. Penyiangan dilakukan setiap ada tanaman pengganggu dan setelah $17 \mathrm{hst}$ penyiangan dilakukan setiap hari. Pengendalian hama dilakukan secara manual. Pemanenan dilakukan dengan cara mencabut seluruh bagian tanaman pada umur 37 hst.
Analisis ragam dilakukan pada hasil pengamatan dari variabel respons berupa daya kecambah, kecepatan tumbuh, jumlah daun, jumlah penambhan daun, luas daun, tinggi tanaman, bobot segar per tanaman (hasil), NPA dan bobot kering total per tanaman. Dengan model linear :

\section{$\sum \mathrm{ijk}$}

$$
Y i j k=\mu+r i+c j+d k+(c d) j k+
$$

Keterangan :

$$
\begin{aligned}
\text { Yijk }= & \text { hasil pengamatan pada } \\
& \text { perlakuan ke-j dan ke-k pada } \\
& \text { ulangan ke-i } \\
\mu & \text { rata-rata umum } \\
\mathrm{ri} \quad & \text { pengaruh ulangan ke-i } \\
\mathrm{cj} \quad & \text { pengaruh perlakuan takaran } \\
& \text { konsentrasi GA3 ke-j } \\
\mathrm{dk}= & \text { pengaruh perlakuan dosis } \\
& \text { pupuk N ke-k } \\
(\mathrm{cd}) \mathrm{jk}= & \text { pengaruh interaksi takaran } \\
& \text { konsentrasi GA3 taraf ke-j } \\
& \text { dan dosis pupuk } \mathrm{N} \text { taraf ke-k } \\
\sum \mathrm{ijk}= & \text { pengaruh galat percobaan }
\end{aligned}
$$

Jika hasil uji sidik ragam menunjukkan keragaman yang nyata, maka untuk mengetahui perbedaan diantara masingmasing perlakuan, analisis dilakukan dengan menggunakan Uji Jarak Berganda Duncant (DMRT) pada taraf nyata $5 \%$.

\section{HASIL DAN PEMBAHASAN}

Selama percobaan berlangsung terdapat gangguan yang relatif sedikit. Selain dikarenakan percobaan dilakukan dalam rumah plastik, lingkungan sekitar adalah daerah persawahan yang ditanami padi sehingga memiliki jenis hama dan penyakit yang berbeda. Gangguan pada tanaman berasal dari beberapa jenis gulma dan hama. Gulma yang tumbuh pada media tanaman selada antara lain rumput, semanggi, putri malu, dan babadotan. Tingkat gangguan gulma tersebut tidak terlalu besar. Gulma tersebut dikendalikan 
secara manual dan waktu pengendalian disesuaikan dengan pertumbuhan gulma Adapun hama yang mengganggutanaman selada selama percobaan diantaranya siput dan ulat jengkal. Kedua hama ini memiliki gejala serangan yang hampir sama yaitu daun berlubang atau sobek. Tingkat gangguan hampir tidak berarti.

Suhu rata-rata selama percobaan $27,54^{\circ} \mathrm{C}$ dan kelembaban rata-rata $65,76 \%$. Menurut Samadi (2014), suhu rata-rata harian yang sesuai untuk pertumbuhan tanaman selada adalah $15^{\circ} \mathrm{C}-20^{\circ} \mathrm{C}$. Akan tetapi selada bisa tetap tumbuh dengan baik sampai suhu $30^{\circ} \mathrm{C}$. Sedangkan kelembaban udara yang sesuai adalah $80 \%-90 \%$.

\section{Daya Kecambah}

Hasil analisis statistik menunjukkan bahwa daya tumbuh benih selada tidak berbeda nyata antara konsentrasi $\mathrm{GA}_{3} 0 \mathrm{mgL}^{-1}$ larutan, 20 $\mathrm{mgL}^{-1}$ larutan, $40 \mathrm{mgL}^{-1}$ larutan dan 60 $\mathrm{mgL}^{-1}$ larutan.

\section{Kecepatan Tumbuh}

Kecepatan tumbuh tanmaan selada tidak berbeda nyata . hal tersebut ditunjukkan dari hasil analisis antara konsentrasi $\mathrm{GA}_{3} 0 \mathrm{mgL}^{-1}$ larutan, 20 $\mathrm{mgL}^{-1}$ larutan, $40 \mathrm{mgL}^{-1}$ larutan dan 60 $\mathrm{mgL}^{-1}$ larutan.

\section{Jumlah Daun}

Hasil analisis menunjukkan tidak terjadi interaksi antara konsentrasi $\mathrm{GA}_{3}$ dan dosis pupuk $\mathrm{N}$ terhadap jumlah daun tanaman selada. Kondisi tersebut terlihat baik pada umur 22 hst, 27 hst, 32 hst maupun 37 hst. Adapun hasil pengujian efek mandiri dari masingmasing perlakuan terhadap jumlah daun pada umur 22 hst dan 32 hst konsentrasi $\mathrm{GA}_{3} 60 \mathrm{mgL}^{-1}$ larutan memberikan jumlah daun yang terbaik dan berbeda nyata dengan konsentrasi lainnya.
Secara umum jumlah daun terbanyak pada kisaran penambhan konsentrasi $\mathrm{GA}_{3} 40 \mathrm{mgL}^{-1}$ larutan-60 mgL $\mathrm{mg}^{-1}$ larutan. Sedangkan dosis pupuk $\mathrm{N}$ yang mengakibatkan jumlah daun tanaman selada terbanyak ada pada kisaran 0,48 $\mathrm{g} \mathrm{polybag}^{-1}-0,72 \mathrm{~g}$ polybag $^{-1}$.

\section{Penambahan Jumlah Daun}

Penambahan jumlah daun tanaman selada tidak menunjukkan adanya interaksi penambahan $\mathrm{GA}_{3}$ dan dosis pupuk N. Akan tetapi pada pengujian efek mandiri pada masingmasing perlakuan baik penambahan konsentrasi $\mathrm{GA}_{3}$ maupun dosis pupuk $\mathrm{N}$ terdapat konsentrasi dan dosis tertentu yang berbeda nyata bpada taraf $5 \%$. Penambahan jumlah daun terbanyak ada pada kisaran penambahan konsentrasi $\mathrm{GA}_{3} 40 \mathrm{mgL}^{-1}$ larutan - $60 \mathrm{mgL}^{-1}$ larutan. Sedangkan dosis pupuk N yang memberikan hasil penambahan jumlah daun terbanyak pada kisaran dosis pupuk $\mathrm{N} 0,48 \mathrm{~g}$ polybag $^{-1}-0,72 \mathrm{~g}$ polybag $^{-1}$.

\section{Tinggi Tanaman}

Pada pengamatan dan analisis data tinggi tanaman selada tidak terdapat interaksi antara pemberian konsentrasi $\mathrm{GA}_{3}$ dan dosis pupuk $\mathrm{N}$. Sedangkan pada masing-masing perlakuan baik penambhan konsentrasi $\mathrm{GA}_{3}$ maupun dosis pupuk $\mathrm{N}$ terlihat bahwa tinggi tanaman selada memiliki perbedaan yang nyata. Tanaman selada tertinggi dapat diakibatkan penambahan konsentrasi $\mathrm{GA}_{3}$ berkisar $40 \mathrm{mgL}^{-1}$ larutan - $60 \mathrm{mgL}^{-1}$ larutan. Adapun dosis pupuk $\mathrm{N}$ yang memberikan tinggi tanaman selada tertinggi berkisar $0,48 \mathrm{~g}$ polybag $^{-1}-0,72 \mathrm{~g}_{\text {polybag }}{ }^{-1}$.

\section{Luas Daun}

Dari hasil analis luas daun tanaman selada tidak menunjukkan adanya interaksi antara penambahan 
konsentrasi $\mathrm{GA}_{3}$ dan dosis pupuk $\mathrm{N}$ pada umur 22 hst, 27 hst dan 32 hst. Sedangkan pada umur 37 hst, perlakuan pemberian konsentrasi $\mathrm{GA}_{3}$ dan dosis pupuk $\mathrm{N}$ menunjukkan adanya interaksi. Luas daun tertinggi pada tanaman selada umur 37 hst ada pada kisaran penambahan $\mathrm{GA}_{3} 40 \mathrm{mgL}^{-1}$ larutan $-60 \mathrm{mgL}^{-1}$ larutan yang disertai dengan dosis pupuk $\mathrm{N} 0,48 \mathrm{~g}^{\text {polybag }}{ }^{-1}$ $-0,72$ g polybag $^{-1}$.

\section{Bobot Segar}

Pengamatan terhadap bobot segar pada tanaman selada di 37 hst menunjukkan adanya interaksi konsentrasi $\mathrm{GA}_{3}$ dan dosis pupuk $\mathrm{N}$. Nilai bobot segar yang tertinggi pada tanaman selada umur 37 hst ada pada kisaran penambahan konsentrasi $\mathrm{GA}_{3} 40$ $\mathrm{mgL}^{-1}$ larutan - $60 \mathrm{mgL}^{-1}$ larutan yang disertai dengan dosis pupuk $\mathrm{N} 0,48 \mathrm{~g}$ polybag $^{-1}-0,72$ g polybag $^{-1}$.

Tabel 2. Pengruh Konsentrasi GA 3 dan Dosis Pupuk N terhadap Bobot Segar Tanaman Selada pada Umur 37 hst

\begin{tabular}{|c|c|c|c|c|}
\hline \multirow{2}{*}{$\begin{array}{c}\text { Konsentrasi } \mathrm{GA}_{3}(\mathrm{C}) \\
\left(\mathrm{mgL}^{-1} \text { larutan }\right)\end{array}$} & \multicolumn{4}{|c|}{ Dosis pupuk N (D)(g polybag $\left.{ }^{-1}\right)$} \\
\hline & $\mathrm{d} 1(0,00)$ & $\mathrm{d} 2(0,24)$ & $\mathrm{d} 3(0,48)$ & $\mathrm{d} 4(0,72)$ \\
\hline & \multicolumn{4}{|c|}{ Bobot segar $(\mathrm{g})$} \\
\hline c1 (0) & $11,75 \mathrm{~b} \mathrm{~A}$ & 12,20 a $\mathrm{A}$ & 12,10 a $\mathrm{A}$ & 17,28 a A \\
\hline c2 (20) & 6,88 a $\mathrm{A}$ & 22,28 a B & 15,43 a B & 15,23 a $\mathrm{B}$ \\
\hline c3 (40) & 17,05 bc A & $22,00 \mathrm{~b} \mathrm{AB}$ & 27,20 b B & 27,95 b B \\
\hline c4 (60) & 20,23 с $\mathrm{AB}$ & 19,25 b A & 29,95 b B & 34,40 b B \\
\hline
\end{tabular}

Keterangan : angka rata-rata yang ditandai dengan huruf kapital yang sama (arah horizontal) dan huruf kecil yang sama (arah vertikal) menunjukkan berbeda tidak nyata menurut uji jarak berganda Duncan pada taraf nyata $5 \%$.

\section{Nisbah Pupus Akar}

Hasil analisis terhadap nisbah pupus akar menunjukkan tidak adanya interaksi. Demikian pula dengan analisis efek mandiri masing-masing perlakuan menunjukkan nilai yang tidak berbeda nyata.

\section{Bobot Kering Total}

Dari hasil analisis terlihat adanya interaksi antara $\mathrm{GA}_{3}$ dan dosis pupuk $\mathrm{N}$. Nilai bobot kering yang tertinggi pada tanaman selada umur 37 hst ada pada penambahan $\mathrm{GA}_{3} \quad 60 \mathrm{mgL}^{-1}$ larutan yang disertai dengan dosis pupuk $\mathrm{N}$ 0,72 g polybag $^{-1}$.

Tabel 3. Pengaruh Konsentrasi $\mathrm{GA}_{3}$ dan Dosis Pupuk $\mathrm{N}$ terhadap Bobot Kering total Tanaman Selada pada Umur 37 hst

\begin{tabular}{ccccc}
\hline Konsentrasi GA & \multicolumn{5}{c}{ Dosis pupuk N $\left.(\mathrm{D})(\mathrm{g} \mathrm{polybag})^{-1}\right)$} \\
\cline { 2 - 5 }$(\mathrm{C})\left(\mathrm{mgL}^{-1}\right.$ larutan $)$ & $\mathrm{d} 1(0,00)$ & $\mathrm{d} 2(0,24)$ & $\mathrm{d} 3(0,48)$ & $\mathrm{d} 4(0,72)$ \\
\hline & & \multicolumn{5}{c}{ Bobot kering total $(\mathrm{g})$} \\
$\mathrm{c} 1(0)$ & 0,55 a A & 0,58 a A & 0,53 a A & 0,83 a A \\
c2 $(20)$ & 0,35 a A & 0,63 a AB & 1,00 ab B & $0,80 \mathrm{~b} \mathrm{~B}$ \\
c3 (40) & 0,78 a A & 0,90 a A & $1,13 \mathrm{~b} \mathrm{~A}$ & $1,73 \mathrm{~b} \mathrm{~B}$ \\
c4 (60) & 0,85 a A & 0,95 a A & 1,18 b A & 2,35 c B \\
\hline
\end{tabular}

Keterangan : angka rata-rata yang ditandai dengan huruf kapital yang sama (arah horizontal) dan huruf kecil yang sama (arah vertikal) menunjukkan berbeda tidak nyata menurut uji jarak berganda Duncan pada taraf nyata 5\% 
Perkecambahan sangat dipengaruhi tersedianya air, oksigen, suhu dan cahaya. Adapun air, oksigen dan suhu adalah hal sangat esensi (Srivastava dan Simarski, 1986). Terlebih bila air tersebut ditambahkan $\mathrm{GA}_{3}$. Penambahan konsentrasi $\mathrm{GA}_{3}$ dengan merendam benih selama 15 menit diharapkan mampu memberikan pengaruh terhadap perkecambahan benih selada. Akan tetapi pada percobaan ini tidak menunjukkan perbedaan yang nyata diantara masingmasing perlakuan terhadap daya tumbuh dan kecepatan tumnuh tanaman selada. Bisa terjadi dimungkinkan karena $\mathrm{GA}_{3}$ yang dipakai lambat terurai, namun selama pertumbuhan aktif, sebagian $\mathrm{GA}_{3}$ dimetabolismekan dengan cepat melalui proses hidroksilasi yang menghasilkan produk yang tidak aktif (Salisbury dan Cleon, 1995). Giberelin juga mudah diubah menjadi konjugat yang sebagian besar tidak aktif. Konjugat ini memungkinkan disimpan atau dipindahkan sebelum dilepaskan pada saat dan tempat yang tepat.

Pada umur selada 22 hst, 27 hst dan 32 hst tidak ditemukan interaksi penggunaan konsentrasi $\mathrm{GA}_{3}$ dan dosis pupuk N. Namun pada analisis efek mandiri didapat adanya pengaruh masing-masing perlakuan pada tanaman selada. Pemberian konsentrasi $\mathrm{GA}_{3}$ berpengaruh terhadap jumlah daun, penambhan jumlah daun, tinggi tanaman 22 hst dan 32 hst serta berpengaruh pada luas daun. Yang perlu diperhatikan dalam pemberian $\mathrm{GA}_{3}$ adalah waktu dan konsentrasi aplikasi karena dalam jumlah berlebih $\mathrm{GA}_{3}$ justru akan menghambat pertumbuhan tanaman atau membuat tanaman lemah dan rebah sehingga mempercepat tanaman mati.

Pemberian beberapa dosis pupuk $\mathrm{N}$ secara umum juga memberikan pengaruh terhadap pertumbuhan tanaman selada. Dosis pupuk $\mathrm{N}$ berpengaruh pada jumlah daun dan penambhan jumlah daun pada 32 hst dan 37 hst, tinggi tanaman (22 hst, 27 hst dan 32 hst ) serta luas daun 27 hst dan 32 hst. Syarief (1986) menyatakan bahwa ketersediaan $\mathrm{N}$ yang cukup mempunyai peranan utama untuk mernagsang pertumbuhansecara keseluruhan dan khususnya pertumbuhan tinggi tanaman. Secara umum kisaran dosis pupuk $\mathrm{N} \mathrm{0,48} \mathrm{g}$ polybag $^{-1}$ sampai dengan dosis $\mathrm{N} 0,72$ $\mathrm{g}_{\text {polybag }}{ }^{-1}$ memberikan hasil terbaik.

Interaksi penggunaan konsentrasi $\mathrm{GA}_{3}$ dan dosis pupuk $\mathrm{N}$ berbeda nyata pada luas daun tanaman selada umur 37 hst, bobot segar per tanaman selada dan bobot kering tanaman selada pada umur 37 hst. Dari analisis interaksi terbaik yang menghasilkan luas daun dan bobot segar per tanaman selada maksium adalah kisaran konsentrasi $\mathrm{GA}_{3} 40 \mathrm{mgL}^{-}$ 1 larutan sampai dengan konsentrasi $\mathrm{GA}_{3} \quad 60 \mathrm{mgL}^{-1}$ larutan yang disertai penambahan kisaran dosis pupuk $\mathrm{N} 0,48$ $\mathrm{g}$ polybag $^{-1}$ sampai dengan dosis pupuk $\mathrm{N} 0,72 \mathrm{~g} \mathrm{polybag}^{-1}$. Adapun pada bobot kering per tanaman yang terbaik pada konsentrasi $\mathrm{GA}_{3} \quad 60 \mathrm{mgL}^{-1}$ larutan dengan dosis pupuk $\mathrm{N} 0,72 \mathrm{~g}_{\text {polybag }}{ }^{-1}$. Interaksi baru terjadi pada $37 \mathrm{hst}$ dimungkinkan adanya proses yang cukup lama pada tanaman dalam merespon perlakuan yang diberikan. Akar tanaman memerlukan waktu yang cukup untuk menyerap dosis pupuk N. Mahrita (2003) menyatakan semakin tinggi dosis pupuk yang diberikan maka akan semakin terpenuhi kebutuhan $\mathrm{N}$ untuk tanaman. Namun dosis $\mathrm{N}$ yang berlebih akan mengakibatkan daun lebih tipis, lebar dan menguning yang menjadikan tanaman lebih lemah. Unsusr $\mathrm{N}$ sangat penting dalam proses fotosintesis yang akhirnya akan mempengaruhi pertumbuhan tanaman. 
Secara umum penambahan konsentrasi $\mathrm{GA}_{3}$ dan dosis pupuk $\mathrm{N}$ memberikan dampak positif terhadap pertumbuhan tanaman selada. Pertumbuhan yang baik akan mengakibatkan tingginya hasil pada tanaman selada.

\section{Kesimpulan}

Berdasarkan hasil percobaan dapat dikemukaan sebagai berikut :

1. Terjadi pengaruh interaksi antara konsentrasi $\mathrm{GA}_{3}$ dan dosis pupuk $\mathrm{N}$ terhadap luas daun umur $37 \mathrm{hst}$, bobot segar per tanaman dan bobot kering per tanaman. Tidak terjadi pengaruh interaksi antara konsentrasi $\mathrm{GA}_{3}$ dan dosis pupuk $\mathrm{N}$ terhadap jumlah daun, penambahan jumlah daun, tinggi tanaman pada umur 22 hst, 27 hst, 32 hst, dan 37 hst, luas daun pada umur $22 \mathrm{hst}, 27 \mathrm{hst}$, dan 32 hst serta nisbah pupus akar.

2. Pemberan konsentrasi $\mathrm{GA}_{3} 40 \mathrm{mgL}^{-1}$ $-60 \mathrm{mgL}^{-1}$ dan dosis pupuk $\mathrm{N} 0,48 \mathrm{~g}$ polybag $^{-1}-0,72 \mathrm{~g}$ polybag $^{-1}$ memberikan luas daun umur $37 \mathrm{hst}$ dan bobot segar/hasil yang lebih baik, sedangkan pemberian konsentrasi $\mathrm{GA}_{3} 60 \mathrm{mgL}^{-1}$ dan dosis

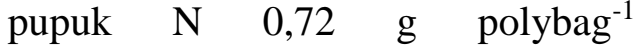
memberikan bobot kering umur 37 hst yang terbaik.

\section{DAFTAR PUSTAKA}

Arifin, Z., P. Yudono, dan Toekidjo. 2012. Pengaruh Konsentrasi $\mathrm{GA}_{3}$ terhadap Pembungaan dan Kualitas Benih Cabai Merah Keriting (Capsicum annuum L.)

Haryanto, Tina S., dan Estu R. 1995. Sawi dan Selada. Penebar Swadaya. Jakarta.

Henny, R.J. and J. Chen. 2011. Using Gibberellic Acid and Ethephon to Induce Flowers on Tropical Foliage Plants. ENH1186. The
Environmental Horticulture

Departement, Florida Cooperative

Extension Service, Institute of

Food and Agricultural Sciences,

University of Florida. Visit the

EDIS website at http://edis.ifas.ufl.edu. P 1-5.

Mahrita. 2003. Pengaruh Pemupukan N dan Waktu Pemangkasan Pucuk terhadap Pertumbuhan dan Hasil Kacang Nagara. Agriscientiae Vol 10 (2) Agustus 2003.

Nugroho. 2005. Pengaruh Dosis Urea dan Jarak Tanam terhadap Pertumbuhan dan Hasil Tanaman Selada (Lactuca sativa L.)

Ogawa, M., A. Hanada, Y. Yamauchi, A. Kuwahara, Y. Kamiya, and S. Yamaguchi. 2003. Gibberellin Biosynthesis and Response during Arabidopsis Seed Germination. The Plant Cell, Vol. 15, 15911604, July 2003, www.plantcell.org c 2003 American Society of Plant Biologists. Page 1591-1604.

Samadi, B., Ir. 2014. Rahasia Budidaya Selada, Teknik Budidaya Pertanian Organik dan Anorganik. Pustaka Mina. Jakarta.

Salisbury, Frank B., dan Cleon W. Ross. 1995. Fisiologi Tumbuhan Jilid 3 (terjemahan). Bandung.

Srivastka, J.P and Simarski, L.T. (Ods). 1986. Seed Production Technology. Internasional Centre for Agrucultural Risearch in the Dry Areas (ICARDA), Aleppo, Syria.

Surtinah, 2010. Pengujian Pupuk Hantu terhadap Perkecambahan Benih Selada (Lactuca sativa L.). Jurnal ilmiah Pertanian Vo. 7 No.2 Hal. 30-37.

Syarief, S., 1986. Kesuburan dan Pemupukan Tanah Pertanian. Pustaka Buana, Bandung. 